\title{
Assessment of Selected Barangays \\ in Makati City Towards Improved Barangay Governance
}

\author{
Rosalyn R. Flores \\ (email: bengflores1530@gmail.com)
}

\begin{abstract}
In international development as noted at the Wikipedia, good governance is a subjective term that describes how public institutions conduct public affairs and manage public resources in the preferred way. Governance is the process of decision - making and the process by which decisions are implemented or not. The term governance can apply to corporate, international, national, local governance or to the interactions between other sectors in the society. (1) "What is Good Governance". UNESCAP, 2009. Accessed July 10, 2009.

This paper explores the concept of good governance from different perspective that then emerges as a model to compare ineffective economies or political bodies with viable economies and political bodies. The concept centers on the responsibility of governments and governing bodies to meet the needs of the masses as opposed to select groups in society. Because countries often described as most successful are liberal democratic states concentrated in Europe and the Americas( 2) Khan, Mushtaq Husain (2004). State formation in Palestine: viability and governance during a social transformation: Volume 2 of Political economy of the Middle East and North Africa. Routledge. ISBN 978-0-415-33802-8. found at Google Books, good governance standards often measure other state institutions against these states. Aid organizations and the authorities of developed countries often will focus the meaning of "good governance " to a set of requirements that conform to the organization agenda, making good governance imply many different things in many different contexts.

(3) Poluha, Eva; Rosendahl, Mona (2002). Contesting 'good' governance:crosscultural perspectives on representation, accountability and public space. Routledge. ISBN 978-07007-1494-0.Thus this paper would adopt the concept of good governance in the Philippine context particularly at the grass root level- the barangay which is considered as the smallest political and yet influential political body in the society.

This paper presents the focal area of good governance in terms of delivering public services to the people from different sectors of the society such as Education and Healthcare, Social Protection, Financial Management, Peace and Security, Business Friendliness, Tourism, Environmental Management and Disaster Preparedness.(4) DILG Memorandum Circular No. 2018-194 dated November 6, 2018.

There will be some indicators and data requirements in each area of services that would suggest, prove and validate that good governance at the grass root level are met.

Through these strategies, the abilities of public sector institutions particularly the barangays in the City of Makati as well as the entire country to deliver key services more effectively and efficiently will be strengthened an these would help a range of public private,
\end{abstract}


civil society partners and stakeholders expand access to and improve the quality of community services.

\section{Keywords:}

good governance; barangay; sustainable development goals; data; public service; Punong barangay; assessment; local government unit; decision-making; implementing; monitoring; transparency; participation

\section{Introduction}

The barangay is the basic political unit, serving as the primary planning and implementing unit of government policies, plans, programs, projects, and activities in the community; it also serves as a forum wherein the collective views of the people may be expressed, crystallized, and considered and where disputes may be amicably settled. (5) Local Government -Barangays", The Information Site on Philippine Politics and Government, Philippine Center of Investigative Journalism. (Online). Available: http://www.isite.ph/Factfinder/barangay.html. The Barangay government is also given considerable autonomy to manage its own affairs, as well as to explore any possibilities of raising its financial resources and utilizing them according to their own discretion, so long as this will result to the improvement of the welfare of its constituents. But in order to fulfill the barangays' mandates and functions, as contained in the Local Government Code, the barangays must be equipped with the necessary competencies, not only in terms of administrative capabilities but also the focal areas of good governance in terms of delivering public services to the people from different sectors of the society such as Education and Healthcare, Social Protection, Financial Management, Peace and Security, Business Friendliness, Tourism, Environmental Management and Disaster Preparedness.

There will be some indicators and data requirements in each area of services that would suggest, prove and validate that good governance at the grass root level are met.

Through these strategies, the abilities of public sector institutions particularly the barangays in the City of Makati as well as the entire country to deliver key services more effectively and efficiently will be strengthened an these would help a range of public private, civil society partners and stakeholders expand access to and improve the quality of community services. 
Since the enactment of the Local Government Code of the Philippines, various capacity building efforts from the national government, academic institutions, and other consulting and training organizations have resulted to a number of tangible improvements in the manner the barangays manage their local affairs. However, despite the clamor for improved governance, there has been no clear measure of the level of the capacities of the barangays and on how they apply these capacities. Therefore, there is a need to examine whether the developed and introduced capacities are indeed being applied. There is also a need to prove if these developed and introduced capacities are effective.

The standard and quality of life of the people living in the barangay is dependent on the wide range of services offered by its local government. These services should be provided in an efficient and appropriate level of quality. But as to how well these services are provided is a source of concern among those running the local government. Thus, there is a need to have feedbacks on the effectiveness of the delivery of such services in order to have a basis for improvement.

An effective local monitoring system for local government units has to be established in order to assist the local government units to target appropriate and responsive interventions for poverty reduction and human development [6]. Austere, Panadero, "Local Governance Towards the Millenium Development Goals" Paper Presented During the Regional Conference on Mainstreaming the UNDP Millenium Development Goals in Local Governance in UNP, Vigan City, 2004.

The need to harmonize and integrate some of the existing tools in order for data to be compared across selected barangays in the City of Makati and be able to aggregate data to a higher level should also be emphasized. Moreover, there is a need for LGUs to be assisted in generating accurate local data and information to be able to respond to the needs of their constituents. (7) Austere, Panadero, "Local Governance Towards the Millenium Development Goals" Paper Presented During the Regional Conference on Mainstreaming the UNDP Millenium Development Goals in Local Governance in UNP, Vigan City, 2004. The data gathered in this study will be very useful in determining the strengths and weaknesses of the selected barangays in as far as compliance to some indicators in the Seal of the Barangay Governance is concerned. 
Likewise, results of the study will serve as a basis in identifying which programs and projects are responsive to national development goals. Moreover, the results of the study will serve as baseline information for the city governments regardless of their status as a highlyurbanized or first, second class municipalities among others in monitoring the performance of the barangays within their jurisdiction.

Furthermore, the findings in this study may also guide the city or municipal government officers in allocating financial resources for the barangays. The data gathered in this study will also be very helpful to Barangay officials, for the data can help them become aware of their current status and can thus serve as their basis in preparing their Barangay Development Plan and on how the said plan can be articulated in the barangay budget.

Moreover, findings of the study may enable the barangay officials to identify the areas or aspects of local governance which need to be prioritized or paid immediate attention.

Moreover, as the barangay officials become aware of their current status, they may be encouraged more to participate in strategic planning and budgeting.

On the part of the city officials, the findings of this study may serve as guides in monitoring the performance of the barangays and in allocating financial resources for barangay projects. Likewise, the findings of this study may serve as a basis for the city officials in giving recognition to those barangays which earned exemplary performance.

Furthermore, this study will provide the city officials with helpful ideas regarding the innovative strategies and tested approaches that the said barangays have implemented in line with the promotion of good governance and in pursuance of sustainable development. Hence, best practices along governance by the barangays can better be identified with the help of this study.

Furthermore, this study would be very helpful for the University of Makati, city's premier university, a local state university located in West Rembo, Makati City, as the findings of this study could serve as inputs for the university's initiative to come up with a more extensive and comprehensive program towards improved barangay governance for mandatory enrollment of all barangay officials both elected and appointed in the extension program of the university . 
Makati or simply known as Makati City, is a 1st class highly urbanized city in Metro Manila, Philippines.

Makati is the financial center of the Philippines; it has the highest concentration of multinational and local corporations in the country. (8) "About Makati, Philippines". Makaticity.com. Retrieved June 5,2013. Major banks, corporations, department stores as well as foreign embassies are based in Makati. The biggest trading floor of the Philippine Stock Exchange is situated along the city's Ayala Avenue. (9) "Archived copy". Archived from the original on 2016-03-03. Retrieved 2013-03-26.^ "Makati Business Club". Mbc.com.ph. Retrieved 2013-03-26. Makati is also known for being a major cultural and entertainment hub in Metro Manila. (10) "Tourist information and services on Makati City Philippines". Touristcenter.com.ph. Retrieved 2013-03-26.

According to the 2015 census, it has a population of 582,602 people (11) Census of Population (2015). "National Capital Region (NCR)". Total Population by Province, City, Municipality and Barangay. PSA. Retrieved 20 June 2016. making it as the 17th-largest city in the country and ranked as the 41st most densely populated city in the world with 19,336 inhabitants per square kilometer. Although its population is just half a million, the daytime population of the city is estimated to be more than one million during a typical working day because of the large number of people who go to the city to work, shop, and do business.(12) "NATIONAL CAPITAL REGION (NCR) > Makati City". Department of Tourism. 2009. Retrieved 2013-05-23.Traffic is expected mostly during rush hour and holiday seasons.

Tradition holds that a Tagalog at a swamp on the south of the Pasig River was asked by a visitor, who was Miguel López de Legazpi, for the name of the place. As a result of the language barrier the question was misinterpreted; the Tagalog pointed to the receding tide of the Pasig River, and answered "Makati, kumákáti na" ("Ebbing, the tide is ebbing").(13) "About Makati City in the Philippines". Makaticity.com. 2012-11-28. Retrieved 2013-03-26.

Makati is divided into 33 barangays (the smallest local government units) which handles governance in a much smaller area. These barangays are grouped into two congressional districts where each district is represented by a congressman in the country's House of Representatives. Congressional District I is composed of the barangays 
straddling EDSA, the barangays to the north and west of them, while excluding Guadalupe Viejo and Pinagkaisahan, while District II are to the south and east of District I, including the two aforementioned barangays. The districts used to elect the members of the city council are coextensive with the congressional districts as shown in the table below.

Table1. Barangays in the City of Makati as arranged alphabetically by District.

\begin{tabular}{|c|c|c|c|}
\hline Barangay & Population (2010) & Area (hectares) & District I \\
\hline Bangkal & 23,378 & 74 & $1^{\text {st }}$ \\
\hline Bel-Air & 18,280 & 171 & $1^{\text {st }}$ \\
\hline Carmona & 3,096 & 34 & $1^{\text {st }}$ \\
\hline Dasmariñas & 5,654 & 190 & $1^{\text {st }}$ \\
\hline Forbes Park & 2,533 & 253 & $1^{\text {st }}$ \\
\hline Kasilawan & 5,291 & 9 & $1^{\text {st }}$ \\
\hline La Paz & 7,931 & 32 & $1^{\text {st }}$ \\
\hline Magallanes & 5,576 & 120 & $1^{\text {st }}$ \\
\hline Olympia & 21,270 & 44 & $1^{\text {st }}$ \\
\hline
\end{tabular}

Table1. 1 Barangays in the City of Makati as arranged alphabetically by District.

\begin{tabular}{llllll}
\hline Barangay & \multicolumn{2}{l}{ Population (2004) } & Population (2010) & Area $\left(\mathbf{k m}^{\mathbf{2}}\right)$ & District I \\
\hline Palanan & 16,614 & 17,283 & 65 & $1^{\text {st }}$ \\
\hline Pio del Pilar & 22,495 & 27,035 & 120 & $1^{\text {st }}$ \\
\hline Poblacion & 8,446 & 17,120 & 46 & $1^{\text {st }}$ \\
\hline San Antonio & 12,226 & 11,443 & 89 & $1^{\text {st }}$ \\
\hline San Isidro & 8,686 & 7,589 & 50 & $1^{\text {st }}$ \\
\hline San Lorenzo & 6,487 & 10,006 & 209 & $1^{\text {st }}$ \\
\hline Santa Cruz & 7,419 & 7,440 & 47 & $1^{\text {st }}$ \\
\hline Singkamas & 6,226 & 7,426 & 13 & $1^{\text {st }}$ \\
\hline Tejeros & 16,820 & 13,868 & 29 & $1^{\text {st }}$ \\
\hline Urdaneta & 3,817 & 3,717 & 74 & $1^{\text {st }}$ \\
\hline Valenzuela & 5,908 & 7,261 & 24 & $1^{\text {st }}$
\end{tabular}


Table1. Barangays in the City of Makati as arranged alphabetically by District.

\begin{tabular}{|c|c|c|c|}
\hline Barangay & Population (2010) & Area (hectares) & District II \\
\hline Cembo & 27,998 & 22 & $2^{\text {nd }}$ \\
\hline Comembo & 14,433 & 27 & $2^{\text {nd }}$ \\
\hline East Rembo & 26,433 & 44 & $2^{\text {nd }}$ \\
\hline Guadalupe Nuevo & 18,271 & 57 & $2^{\text {nd }}$ \\
\hline Guadalupe Viejo & 16,411 & 62 & $2^{\text {nd }}$ \\
\hline Pembo & 44,803 & 123 & $2^{\text {nd }}$ \\
\hline Pinagkaisahan & 5,804 & 16 & $2^{\text {nd }}$ \\
\hline Pitogo & 15,332 & 14 & $2^{\text {nd }}$ \\
\hline
\end{tabular}

Table1. Barangays in the City of Makati as arranged alphabetically by District.

\begin{tabular}{|c|c|c|c|}
\hline Barangay & Population (2010) & Area (hectares) & District II \\
\hline \begin{tabular}{c} 
Post Proper Northside \\
\hline (disputed barangay)
\end{tabular} & 6,010 & 238 & $2^{\text {nd }}$ \\
\hline Post Proper Southside & 10,458 & 341 & $2^{\text {nd }}$ \\
\hline (disputed barangay) & 41,959 & 355 & $2^{\text {nd }}$ \\
\hline$\underline{\text { Rizal }}$ & 14,672 & 20 & $2^{\text {nd }}$ \\
\hline$\underline{\text { South Cembo }}$ & 28,406 & 55 & $2^{\text {nd }}$ \\
\hline
\end{tabular}


Table 3. Barangays in the City of Makati as grouped into CLUSTER .

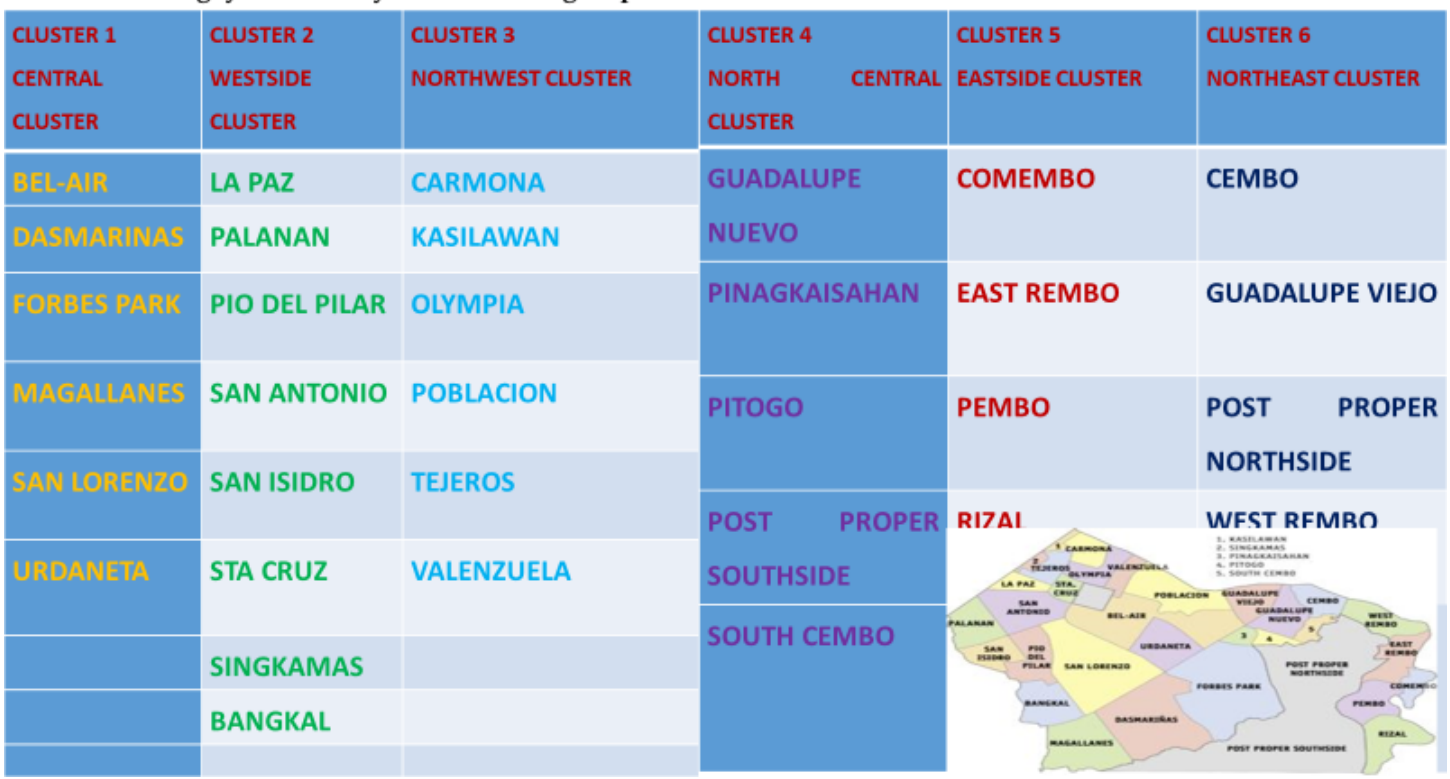

\section{BARANGAY MAPPING}

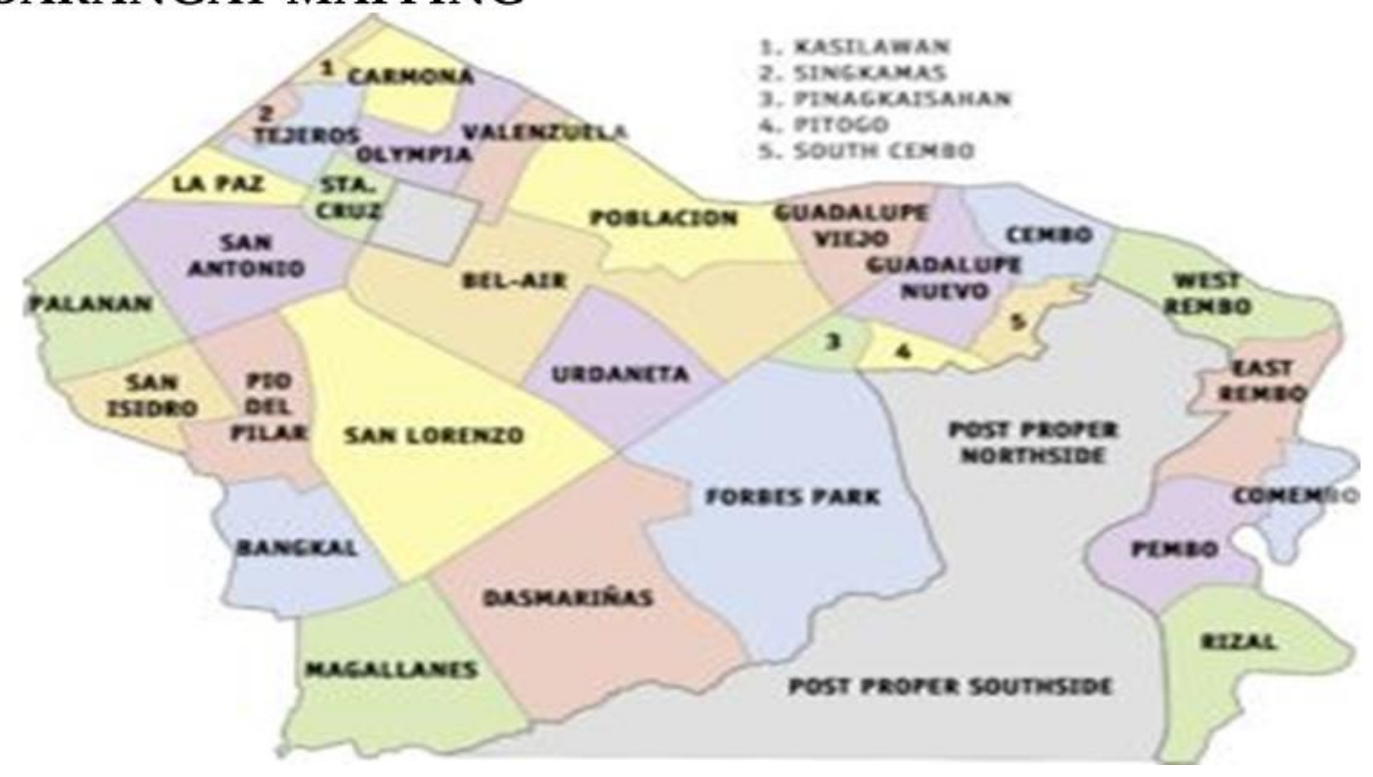

The current mayor for the 2016-2019 term is Abby Binay, the daughter of former mayor and former Vice President Jejomar Binay. Monique Yazmin Q. Lagdameo is the city's incumbent vice mayor. The vice mayor heads a legislative council consisting of 18 members: 8 Councilors from the First District, 8 Councilors from the Second District, the President of the Sangguniang Kabataan (Youth Council) Federation, representing the youth sector, and the 
President of the Association of Barangay Chairmen (ABC) as barangay sectoral representative. The council is in charge of creating the city's policies in the form of Ordinances and Resolutions. Current district representatives of the city are Romulo "Kid" Peña Jr. (14) News, ABS-CBN. "Kid Peña stuns ex-VP Binay in Makati 1st district congressional race". ABSCBN News. Retrieved 2019-06-30., representing the 1st district and Luis Jose Angel Campos Jr., husband of Abby Binay, for the 2nd district.

Makati City has received various awards at the regional level, as well as the national and international levels.

Makati City being the financial capital of the Philippines is filled with gigantic buildings, condominiums, five-star hotels, major banks, corporations, department stores as well as foreign embassies. Makati is also known for being a major cultural and entertainment center in Metro Manila. The local government of Makati has been in existence for 344 years. It was transformed from a municipality into a highly urbanized city on January 2, 1995 through Republic Act 7854 with the great support of the residents in a plebiscite held on February 4, 1995. The reforms implemented by the Mayor are in line with its thrust of installing a local government that is efficient, effective and responsive in delivering the essential services to all Makati constituents.

The sisterhood agreement is one of the projects of the Hon. Jejomar C. Binay who was then the mayor of Makati, now the Vice President of the Philippines. A sister city, municipality relationship becomes official with the signing of a formal agreement by the top elected officials approving a long-term partnership between the two communities. Sister city or municipality relationship between Makati, Metro Manila and other provinces and even foreign countries is continuously expanding through the efforts of Hon. Mayor Jejomar Erwin S. Binay, Jr. It aims to further involve the widest possible diversity of exchanges and projects, such as health care, education, economics and business development. Another is academic exchanges of students whereby they can avail the privileges enjoyed by Makati residents. The benefits of the sister city or municipality relationship include the following: an air of global perspective with a feeling of welcoming, relax, and at ease visiting various locations of the city, provision of free accommodations by the Makati City government in the Friendship Suite, and an escort service upon their arrival from the airport to the place of their destination and until departure. 
Sisterhood agreement merely establishes friendship ties through sharing of experiences and best practices in areas of common interest.

\section{Statement of the Problem}

Generally, this study aimed to assess the level of compliance to indicators for seal of good barangay governance of selected barangays in Makati City towards improved barangay governance.

Specifically, it sought to determine the following:

a. profile of the barangays in terms of population, number of households, and annual income;

b. resources of the barangays that are required to produce goods and services;

c. how the barangays manage its resources to produce goods and service along the following: development planning, local fiscal administration, organization and management, barangay legislation, and community participation ;

d. outputs of the barangays in the delivery of the following services through Education and Healthcare, Social Protection, Financial Management, Peace and Security, Business Friendliness, Tourism, Environmental Management and Disaster Preparedness

e. impacts of the service delivery of the barangays on either intermediate level, or high level

\section{Methodology}

This study used the descriptive research design, utilizing the input-process-outputoutcomes model. It described the barangays' resource requirements, management of resources, delivery of services and the outcomes of the service delivery. The main respondents of the study were the Punong Barangay (Local Chief Executive of the Barangay) and the Barangay Secretaries from the 6 selected barangays of Makati City. Five other residents in each barangay were also taken as respondents in order to validate the data gathered from the Punong Barangay and the Barangay Secretaries.(15) World Academy of Science, Engineering and Technology International Journal of Economics and Management Engineering Vol:2, No:10, 2008 International Scholarly and Scientific Research E Innovation 
2(10) 20081208 ISNI:0000000091950263 Open Science Index, Economics and Management Engineering Vol:2, No:10, 2008 waset.org/Publication/1707. The study used various methods in gathering the data needed. A questionnaire was used in gathering data on the profile of the barangays, as well as in gathering information about barangay resources, barangay processes, barangay outputs, and barangay outcomes or impacts. Most of the items in the questionnaire were based on the questionnaire devised by the Local Government Academy for Barangay Governance and Development Program (16). Crescencio Velasco, "Barangay Governance and Development Program", Paper Presented During the Regional Conference on Mainstreaming the UNDP Millennium Development Goals in Local Governance in UNP, Vigan City. Some of the items in the questionnaire were also based from the LPPMS [17]. Alex Brillantes, Measuring the Performance of Philippine Cities: The Local Productivity and Performance 4Measurement System (LPPMS). [Online]. Available: http:// www.worldbank.org/html/fpd/urban/symposium2002/docs/prespaper/pps/brillantes.pps.

The Punong Barangay and the Barangay Secretary in each barangay were requested to answer the questionnaire. They were likewise requested to provide documents on the facilities and projects of the barangays. In addition, ocular inspections and documentation of the tangible projects in the barangays were done. Five residents in each barangay were also interviewed. Most of the data used in this study were taken from documents filed in the Barangay offices. In the absence of documents in the Barangay level, documents filed at the city level were requested. Data gathered in the barangay were also verified with the data submitted at the city level. This is particularly true for the financial records and accomplishments of the barangays. Processing of the data gathered in this study was done through the use of the following statistical tools: frequency, percentage, mean, and simple ratio and proportion. 
implementing unit of government policies. Performance is equated with the local government's responses to the community's needs, particularly the provision of basic and essential public services. High performance is the result of rational decision-making; optimal use of resources such as funds, personnel, equipment, etc.; and the delivery of basic public services in a timely and sustained manner. Performance can be assessed in terms of the local governments' capabilities to respond to the community's need for basic essential services. Local government performance is then measurable through discernible improvement in the quality of life of individuals, the society as a whole, and more importantly the poor [19]. Rolando Acosta, et al, "Local Government Capability Handbook", Manila: Local Administration and Development Program Alumni Association of the Philippines, Inc, 1991. Performance Measurement is defined as those processes that are utilized to measure the performance of a Local Government body - particularly in relation to its achievement of predetermined outcomes and objectives. [20] Performance Measurement E Management in Asian-Pacific Local Government. The Network of Local Government Training and Research Institutes and the Pacific (LOGOTRI). (Online). Available: http://www.logotri.net/pmsea.pdf. Performance Measurement evaluates the governance and management capacity of LGUs, specifically focusing on the internal capacity of LGUs in the areas of local financial administration, local legislation, organization and management, and local development planning.[8] Performance Management, on the other hand, can be defined as all of those processes (including Performance Measurement) that are utilized to capture the results of performance measurement and feed them back into the planning processes which then guide the organization to make the necessary changes to its activities and modes of operation and (if necessary) make changes to its strategic outcomes and objectives [21). Performance Measurement \& Management in Asian-Pacific Local Government. The Network of Local Government Training and Research Institutes and the Pacific (LOGOTRI). (Online). Available: http://www.logotri.net/pmsea.pdf. The two terms are not interchangeable, rather, they form an integrated part of a total Performance Management Cycle. Functionality has been known to refer to the efficiency or effectiveness of individuals, groups, organizational units, entire organizations, industries, and nations. It is sometimes used interchangeably with such concepts as output, motivation, individual performance, organizational effectiveness, production, profitability, cost/effectiveness, competitiveness, and work quality. Functionality 
may also refer to what a new product will enable one to increase if such product is bought. Productivity measurement is used to refer to performance appraisal, management information systems, production capability assessment, quality control measurement, and the engineering throughput of a system [22] Robert D. Pritchard, Measuring and Improving Organizational Productivity - A Practical Guide. Online available http://books.google.com.ph/books?id=ably-ewzroMCEdc. In assessing the delivery of services in the social, economic, political, and environmental sectors, Functionality Performance is used. In Functionality Performance, the degree of productivity is determined by comparing the actual LGU services against service standards prescribed by the national government agencies concerned. On the other hand, Service Delivery Outcome Assessment is used to determine the effect of the services delivered by the LGUs to the citizen's quality of life, particularly the impact of the services to the socioeconomic conditions of the residents, especially the poor [23]. Philippine Performance Measurement at the Local Level, Final report. 2006. [Online]. Available: World Academy of Science, Engineering and Technology International Journal of Economics and Management Engineering Vol:2, No:10, 2008 International Scholarly and Scientific Research E Innovation 2. In the Philippines, through the Department of Interior and Local Government, Seal of Good Local Governance for Barangay Assessment (SGLGB) is one of the most commonly used performance indicator systems at the barangay level. It is a self assessement LGU performance by measuring multisectoral impact and the presence/number of services, facilities, projects, plans, programs, and policies, while emphasizing on good governance and administration. The result of the evaluation will guide the policy makers in making decisions towards the modification of their strategies in implementing a program. SGLGB can also be used in the identification of bottlenecks or impediments in the program mechanisms for the purpose of early corrective measures in order not to waste resources and energies. The system is essential in determining the LGU particularly the barangay its level of functionality and performance in order to enable local leaders to improve the quality of local policies, programs, and services for greater transparency and accountability in government operations [24] DILG Region 10 Newsletter. [Online]. Available: http://www.dilg10.org/v1/newsletter/2001/JUL01.PDF Local governments also have a very crucial role to play in the attainment of government goals under the Sustainable Development Goals Declaration. The need to encourage local 
governments to reallocate resources towards basic social services and intensify efforts towards the implementation of programs, projects, and activities that are responsive to Sustainable Development Goals or SDG had been underscored time and again. The Sustainable Development Goals is a set of time-bound, measurable goals and targets for combating The 17 sustainable development goals (SDGs) to transform the world:

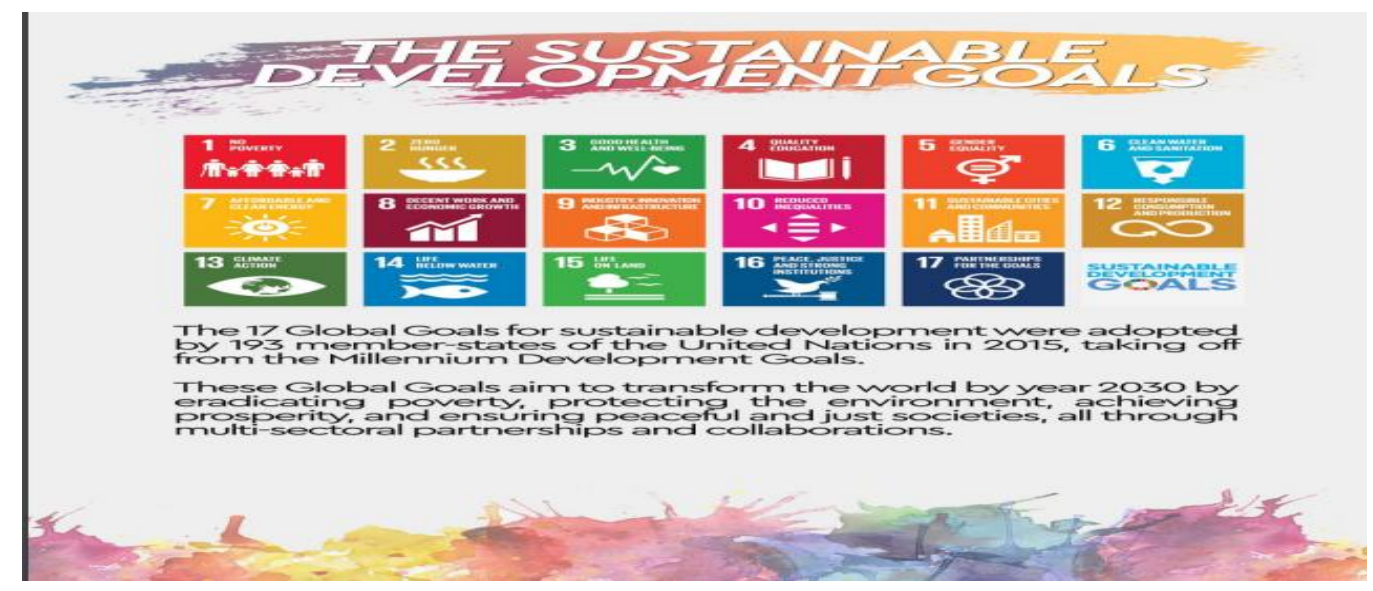

It consists of 17 goals and there are 169 targets for the 17 goals. Each target has between 1 and 3 indicators used to measure progress toward reaching the targets. The innovative strategies and tested approaches in promoting good governance and pursuing sustainable development, are now being implemented in several Philippine communities.

Thus, in keeping with the theme of the campaign, the United Nation's Agenda 2030 and Sustainable Development Goals (SDGs) pick up where the Millennium Development Goals (MDGs) left off. The SDGs set forth a formidable task for the global community and international sustainable development over the next 15 years. Learning from the successes and failures of the MDGs, government officials, development experts, and many other groups understood that localization is necessary to accomplish the SDGs but how and what to localize remain as questions to be answered. [ 25]. Manohar patole id independent Consultant on Environmental Governance. Brooklyn, NY 11218, USA; manny.patole@nyu.edu Received: 4 November 2017; Accepted: 6 February 2018; Published: 5 March 2018 


\section{Results and Discussion}

Table 4.1 BARANGAY PROFILE

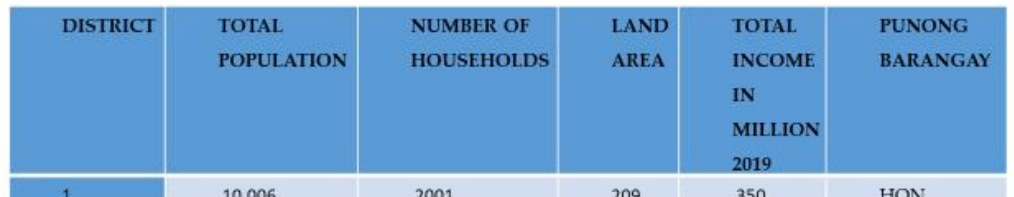

\section{LORENZO}
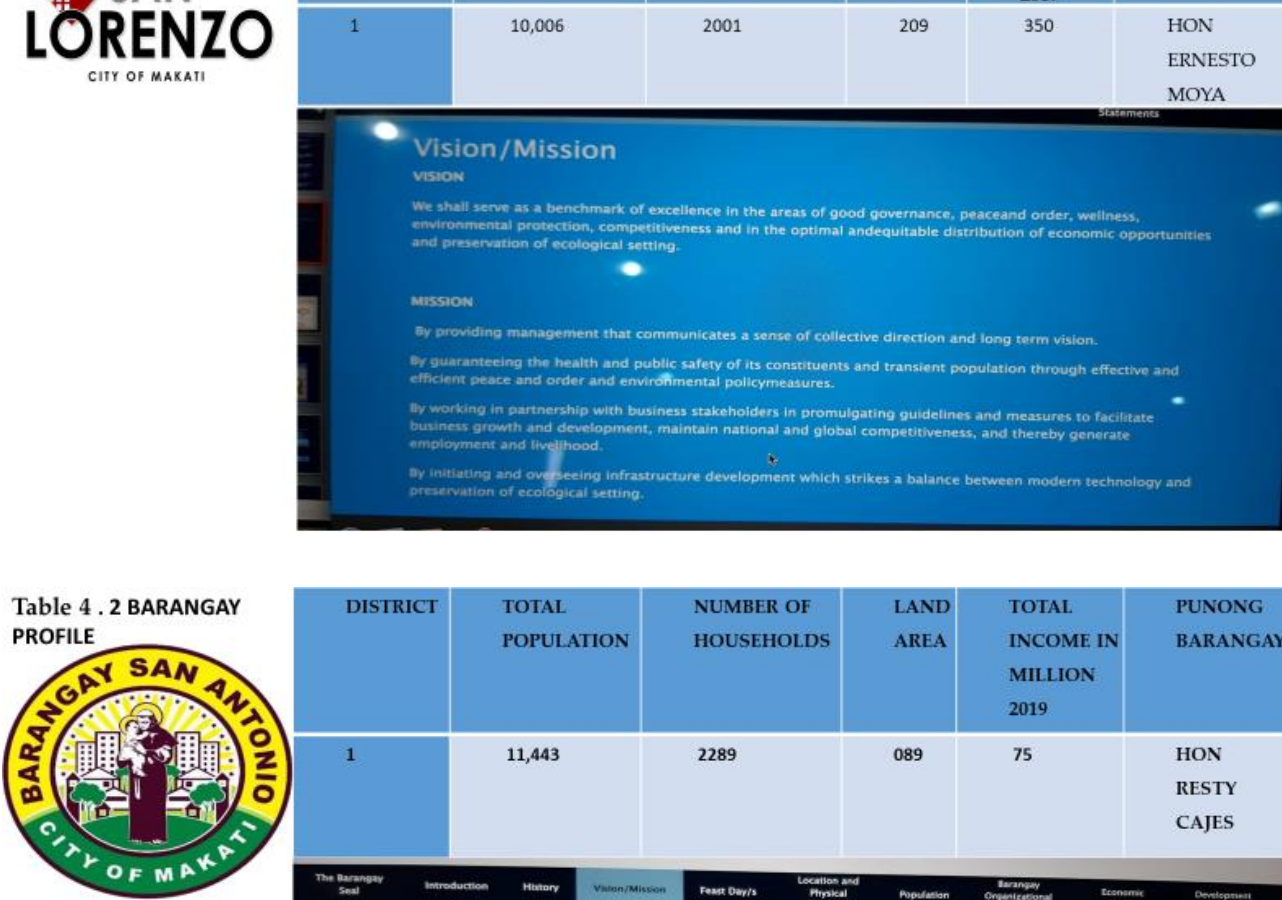

INCOME IN BARANGAY

MIIUON 2019
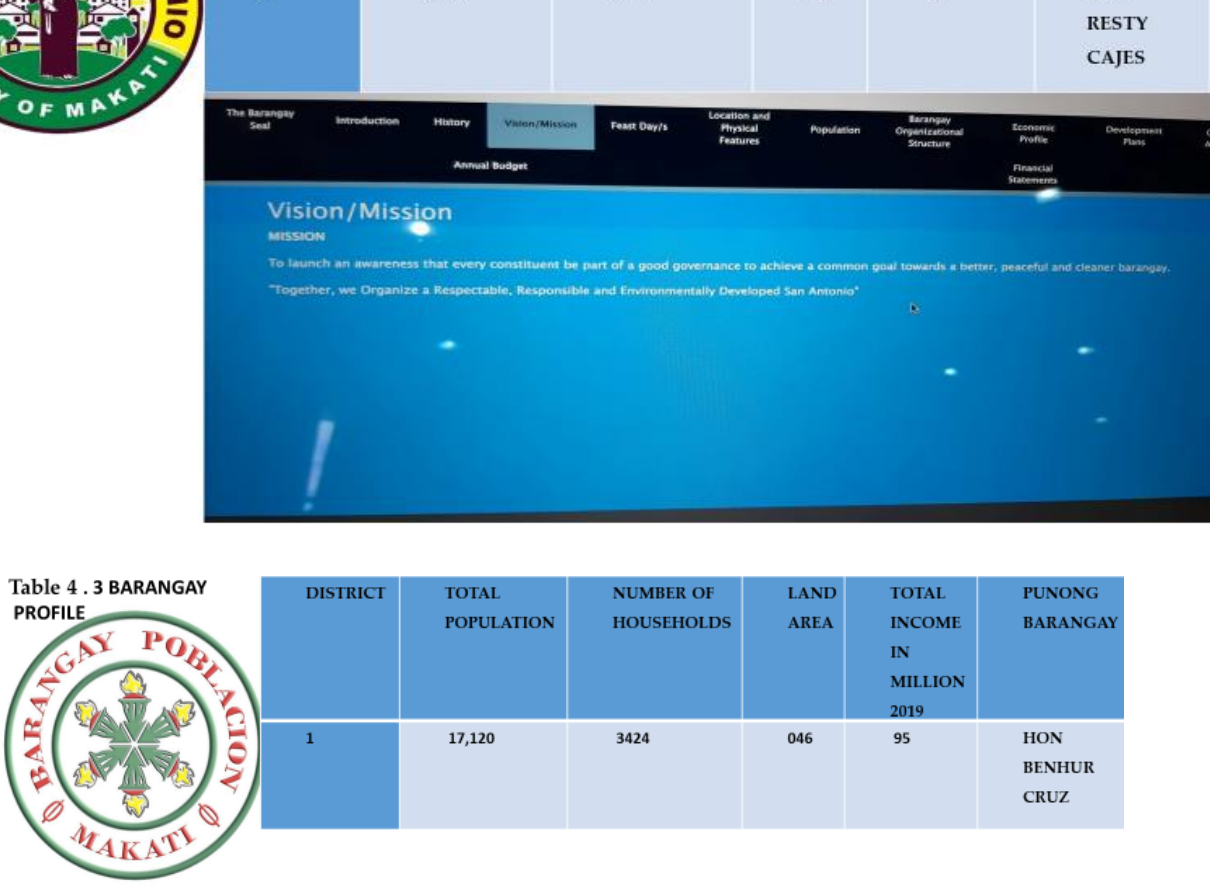

VISION

We envision Barangay Poblacion to be the heritage and cultural center and an economic powerhouse of Makati, with empowered and God-loving residents who are proud of their rich past and are ready to face the challenges and developments of the future.

\section{MISSION}

Increase revenue from economic activities; Reduce unemployment; Improve physical environment which includes beautification of surroundings and conservation of heritage sites; Minimize the incidence of crimes; Eradicate drug addiction; Revive cultural traditions; Increase tourist arrivals; Increase in tourism-related establishments; Inculcate "tourism culture" to residents 

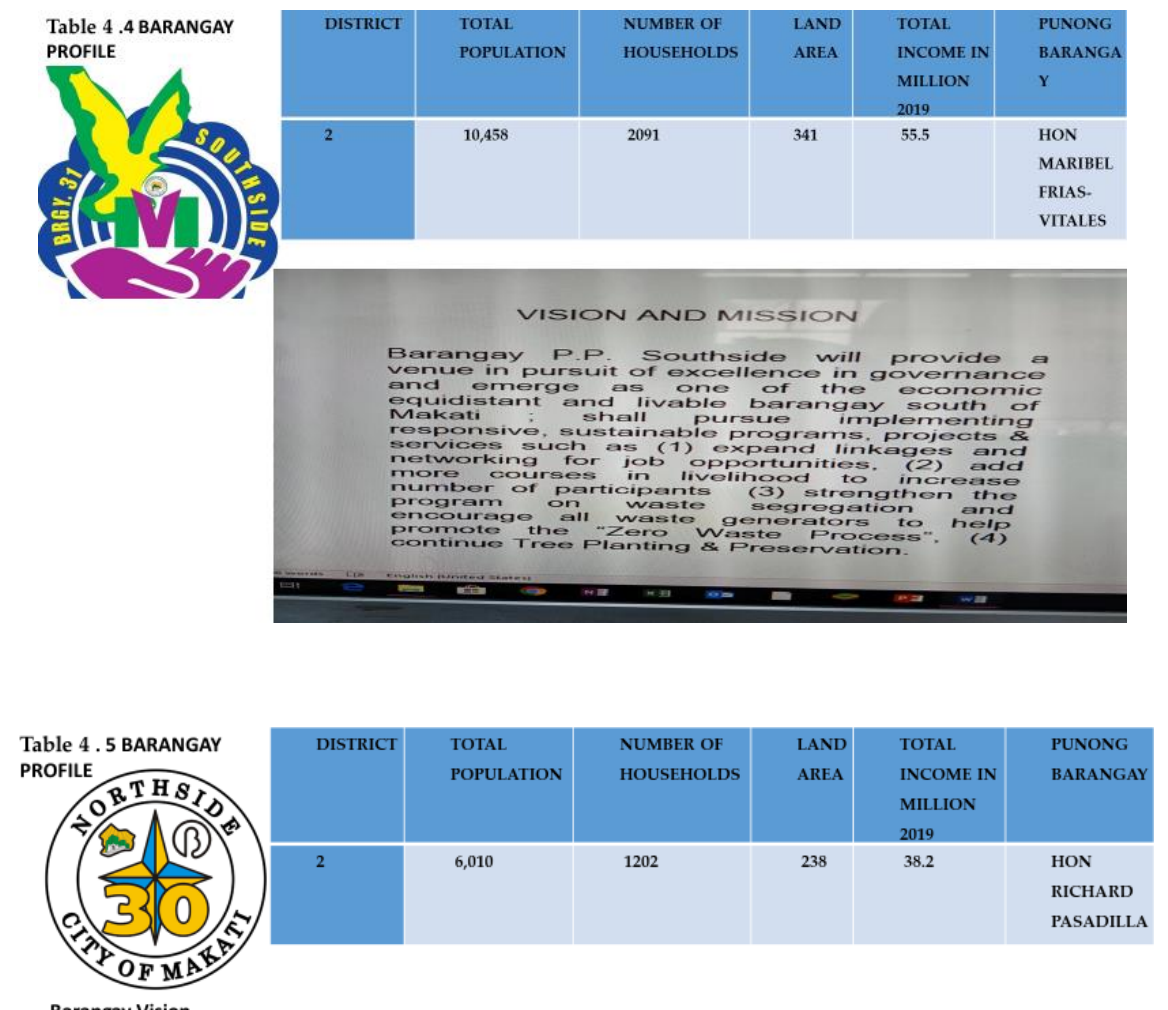

Barangay Vision

Barangay Post Proper Northside shall be the front liner in the pillars of services and sustainability in terms of peace and security environmental sustainability, livelihood opportunities and economic development social services continuity and accessibility , leadership and sports development in District II, City of Makati. Post Proper Northside will be a reachable community that transforms its residents into productive, and competitive citizens of Makati, the Philippines and the of global community.

\section{Barangay Mission}

Barangay Post Proper Northside shall realize its commitment to the community and its people in various sectors in improving quality, fast, efficient and effective services thru well-balanced programs, projects and activities that foster the residents' personal and professional growth in all aspects of their lives in a sectoral gender-sensitive community. 


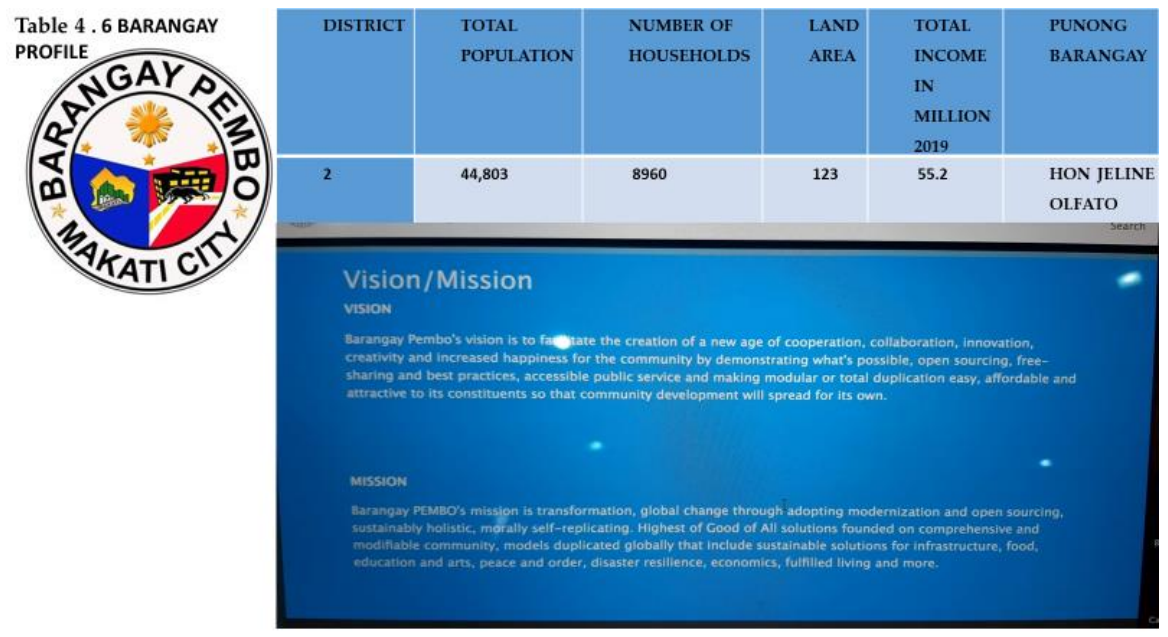


TABLE 5 DISTRIBUTION OF THE BARANGAYS IN TERMS OF AVAILABILITY OF RESOURCES

\begin{tabular}{|c|c|c|c|c|c|}
\hline BARANGAY & $\begin{array}{l}\text { BARANGAY } \\
\text { FACILITIES } \\
\text { AVAILABLE }\end{array}$ & $\begin{array}{l}\text { PRESENCE OF } \\
\text { ANNUAL } \\
\text { INVESTMENT } \\
\text { PROGRAM }\end{array}$ & $\begin{array}{l}\text { PRESENCE OF } \\
\text { BARANGAY } \\
\text { DEVELOPMENT } \\
\text { PLAN }\end{array}$ & \begin{tabular}{l|} 
PRESENCE \\
OF ANNUAL \\
BUDGET
\end{tabular} & $\begin{array}{l}\text { PRESENCE OF } \\
\text { FULL } \\
\text { DISCLOSURE } \\
\text { POLICY BOARD }\end{array}$ \\
\hline San Lorenzo & Barangay Hall & $\begin{array}{l}\text { Approved by the City } \\
\text { Council }\end{array}$ & $\begin{array}{l}\text { Approved by the City } \\
\text { Council }\end{array}$ & $\begin{array}{l}\text { Approved by the } \\
\text { City Council }\end{array}$ & $\begin{array}{l}\text { As mandated by Law } \\
\text { thru DILG }\end{array}$ \\
\hline San Antonio & $\begin{array}{l}\text { Barangay Hall } \\
\text { Covered Court }\end{array}$ & $\begin{array}{l}\text { Approved by the City } \\
\text { Council }\end{array}$ & $\begin{array}{l}\text { Approved by the City } \\
\text { Council }\end{array}$ & $\begin{array}{l}\text { Approved by the } \\
\text { City Council }\end{array}$ & $\begin{array}{l}\text { As mandated by Law } \\
\text { thru DILG }\end{array}$ \\
\hline Poblacion & $\begin{array}{l}\text { Barangay Hall } \\
/ \text { Covered Court } \\
\text { Park /Health Center } \\
\text { Multi-Purpose Hall }\end{array}$ & $\begin{array}{l}\text { Approved by the City } \\
\text { Council }\end{array}$ & $\begin{array}{l}\text { Approved by the City } \\
\text { Council }\end{array}$ & $\begin{array}{l}\text { Approved by the } \\
\text { City Council }\end{array}$ & $\begin{array}{l}\text { As mandated by Law } \\
\text { thru DILG }\end{array}$ \\
\hline $\begin{array}{l}\text { PostProper } \\
\text { Northside } \\
\end{array}$ & Barangay Hall & $\begin{array}{l}\text { Approved by the City } \\
\text { Council }\end{array}$ & $\begin{array}{l}\text { Approved by the City } \\
\text { Council }\end{array}$ & $\begin{array}{l}\text { Approved by the } \\
\text { City Council }\end{array}$ & $\begin{array}{l}\text { As mandated by Law } \\
\text { thru DILG }\end{array}$ \\
\hline Pembo & $\begin{array}{l}\text { Barangay Hall , } \\
\text { Covered Court/ Health } \\
\text { Center }\end{array}$ & $\begin{array}{l}\text { Approved by the City } \\
\text { Council }\end{array}$ & $\begin{array}{l}\text { Approved by the City } \\
\text { Council }\end{array}$ & $\begin{array}{l}\text { Approved by the } \\
\text { City Council }\end{array}$ & $\begin{array}{l}\text { As mandated by Law } \\
\text { thru DILG }\end{array}$ \\
\hline $\begin{array}{l}\text { PostProper } \\
\text { Southside }\end{array}$ & Barangay Hall & $\begin{array}{l}\text { Approved by the City } \\
\text { Council }\end{array}$ & $\begin{array}{l}\text { Approved by the City } \\
\text { Council }\end{array}$ & $\begin{array}{l}\text { Approved by the } \\
\text { City Council }\end{array}$ & $\begin{array}{l}\text { As mandated by Law } \\
\text { thru DILG }\end{array}$ \\
\hline
\end{tabular}

TABLE 6 MANAGEMENT OF RESOURCES ALONG DEVELOPMENT PLANNING AND LOCAL FISCAL ADMINISTRATION

\begin{tabular}{|c|c|c|c|c|c|c|c|}
\hline BARANGAY & $\begin{array}{l}55 \% \\
\text { PERSONAL } \\
\text { SERVICES }\end{array}$ & $\begin{array}{l}\text { 20\%DEVT } \\
\text { FUND }\end{array}$ & $\begin{array}{l}5 \% \text { DRRM } \\
\text { FUND }\end{array}$ & $\begin{array}{l}5 \% \text { GAD } \\
\text { FUND }\end{array}$ & $\begin{array}{l}1 \% B C P C \\
\text { FUND }\end{array}$ & $\begin{array}{l}1 \% \text { PWD AND SENIOR } \\
\text { CITIZENS FUND }\end{array}$ & $10 \%$ SK FUND \\
\hline San Lorenzo & $50-53 \%$ & $95 \%$ & $95 \%$ & $95 \%$ & $95 \%$ & $95 \%$ & $100 \%$ \\
\hline San Antonio & $50-53 \%$ & $95 \%$ & $85 \%$ & $95 \%$ & $95 \%$ & $95 \%$ & $100 \%$ \\
\hline Poblacion & $50-53 \%$ & $95 \%$ & $95 \%$ & $95 \%$ & $95 \%$ & $95 \%$ & $100 \%$ \\
\hline $\begin{array}{l}\text { Post Proper } \\
\text { Northside }\end{array}$ & $45-50 \%$ & $85 \%$ & $85 \%$ & $95 \%$ & $95 \%$ & $95 \%$ & $100 \%$ \\
\hline Pembo & $50-53 \%$ & $95 \%$ & $90 \%$ & $95 \%$ & $95 \%$ & $95 \%$ & $100 \%$ \\
\hline $\begin{array}{l}\text { Post Proper } \\
\text { Southside }\end{array}$ & $50-53 \%$ & $85 \%$ & $90 \%$ & $95 \%$ & $95 \%$ & $95 \%$ & $100 \%$ \\
\hline
\end{tabular}

TABLE 7 MANAGEMENT OF RESOURCES ALONG ORGANIZATION AND MANAGEMENT

\begin{tabular}{|c|c|c|c|c|c|c|}
\hline BARANGAY & $\begin{array}{l}\text { PRESENCE OF } \\
\text { MANUAL OF } \\
\text { OPERATIONS }\end{array}$ & $\begin{array}{l}\text { PRESENCE OF } \\
\text { ACCOMPLISHMENT } \\
\text { REPORT SUBMIITED } \\
\text { ON TIME }\end{array}$ & $\begin{array}{l}\text { PRESENCE OF } \\
\text { BARANGAY- } \\
\text { INIIATED } \\
\text { TRAINING }\end{array}$ & $\begin{array}{l}\text { PRESENCE OF } \\
\text { SERVICEABLE } \\
\text { EQUIPMENI }\end{array}$ & $\begin{array}{l}\text { PRESENCE OF } \\
\text { SERVICEABLE } \\
\text { VEHICLES }\end{array}$ & $\begin{array}{l}\text { RESPONSE TIME IN } \\
\text { THE ISSUANCE OF } \\
\text { BARANGAY } \\
\text { RELATED } \\
\text { CERTIFICATES }\end{array}$ \\
\hline San Lorenzo & Yes & Yes & Yes & Yes & Yes & $\begin{array}{l}\text { less than } 10 \\
\text { minutes as } \\
\text { stipulated in the } \\
\text { Citizens Charter }\end{array}$ \\
\hline San Antonio & Yes & Yes & Yes & Yes & Yes & $\begin{array}{l}\text { less than } 10 \text { minutes as } \\
\text { stipulated in the } \\
\text { Citizens Charter }\end{array}$ \\
\hline Poblacion & Yes & Yes & Yes & Yes & Yes & $\begin{array}{l}\text { less than } 10 \text { minutes as } \\
\text { stipulated in the } \\
\text { Citizens Charter }\end{array}$ \\
\hline $\begin{array}{l}\text { Post Proper } \\
\text { Northside }\end{array}$ & Yes & Yes & Yes & No fax machine & No ambulance & $\begin{array}{l}\text { less than } 10 \text { minutes as } \\
\text { stipulated in the } \\
\text { Citizens Charter }\end{array}$ \\
\hline Pembo & Yes & Yes & Yes & Yes & Yes & $\begin{array}{l}\text { less than } 10 \text { minutes as } \\
\text { stipulated in the } \\
\text { Citizens Charter }\end{array}$ \\
\hline $\begin{array}{l}\text { Post Proper } \\
\text { Southside }\end{array}$ & Yes & Yes & Yes & Yes & Yes & $\begin{array}{l}\text { less than } 10 \text { minutes as } \\
\text { stipulated in the } \\
\text { Citizens Charter }\end{array}$ \\
\hline
\end{tabular}


TABLE 8. MANAGEMENT OF RESOURCES ALONG BARANGAY LEGISLATION

\begin{tabular}{|c|c|c|c|c|c|}
\hline BARANGAY & $\begin{array}{l}\text { PRESENCE OF } \\
\text { INTERNAL RULES OF } \\
\text { PROCEDURE }\end{array}$ & $\begin{array}{l}\text { PRESENCE OF } \\
\text { BARANGAY } \\
\text { AGENDA AND } \\
\text { MINUTES } \\
\end{array}$ & $\begin{array}{l}\text { PASSING OF PROGRAM- } \\
\text { RELATED RESOLUTIONS } \\
\text { and ORDINANCES }\end{array}$ & $\begin{array}{l}\text { COMPLIANCE WITH } \\
\text { THE STANDARD } \\
\text { NUMBER OF } \\
\text { SESSIONS }\end{array}$ & $\begin{array}{l}\text { FREQUENCY OF } \\
\text { HOLDING } \\
\text { BARANGAY } \\
\text { ASSEMBLY } \\
\end{array}$ \\
\hline San Lorenzo & $\begin{array}{l}\text { Using the the } \\
\text { parliamentary } \\
\text { procedures }\end{array}$ & $\begin{array}{l}\text { Prepared by the } \\
\text { Brgy Secretary }\end{array}$ & $\begin{array}{l}\text { Appropriation of Funds and } \\
\text { Tax Code }\end{array}$ & Twice a month & $\begin{array}{l}\text { Semestral-March } \\
\text { and October }\end{array}$ \\
\hline San Antonio & $\begin{array}{l}\text { Using the the } \\
\text { parliamentary } \\
\text { procedures }\end{array}$ & $\begin{array}{l}\text { Prepared by the } \\
\text { Brgy Secretary }\end{array}$ & $\begin{array}{l}\text { Appropriation of Funds and } \\
\text { Tax Code }\end{array}$ & Twice a month & $\begin{array}{l}\text { Semestral -March } \\
\text { and October }\end{array}$ \\
\hline Poblacion & $\begin{array}{l}\text { Using the the } \\
\text { parliamentary } \\
\text { procedures }\end{array}$ & $\begin{array}{l}\text { Prepared by the } \\
\text { Brgy Secretary }\end{array}$ & $\begin{array}{l}\text { Appropriation of Funds and } \\
\text { Tax Code }\end{array}$ & Twice a month & $\begin{array}{l}\text { Semestral -March } \\
\text { and October }\end{array}$ \\
\hline $\begin{array}{ll}\text { Post } & \text { Proper } \\
\text { Northside } & \end{array}$ & $\begin{array}{l}\text { Using the the } \\
\text { parliamentary } \\
\text { procedures }\end{array}$ & $\begin{array}{l}\text { Prepared by the } \\
\text { Brgy Secretary }\end{array}$ & $\begin{array}{l}\text { Appropriation of Funds and } \\
\text { Tax Code }\end{array}$ & Twice a month & $\begin{array}{l}\text { Semestral-March } \\
\text { and October }\end{array}$ \\
\hline Pembo & $\begin{array}{l}\text { Using the the } \\
\text { parliamentary } \\
\text { procedures }\end{array}$ & $\begin{array}{l}\text { Prepared by the } \\
\text { Brgy Secretary }\end{array}$ & $\begin{array}{l}\text { Appropriation of Funds and } \\
\text { Tax Code }\end{array}$ & Twice a month & $\begin{array}{l}\text { Semestral -March } \\
\text { and October }\end{array}$ \\
\hline $\begin{array}{ll}\text { Post } & \text { Proper } \\
\text { Southside } & \end{array}$ & $\begin{array}{l}\text { Using the the } \\
\text { parliamentary } \\
\text { procedures }\end{array}$ & $\begin{array}{l}\text { Prepared by the } \\
\text { Brgy Secretary }\end{array}$ & $\begin{array}{l}\text { Appropriation of Funds and } \\
\text { Tax Code }\end{array}$ & Twice a month & $\begin{array}{l}\text { Semestral -March } \\
\text { and October }\end{array}$ \\
\hline
\end{tabular}

TABLE 9 . MANAGEMENT OF RESOURCES ALONG BARANGAY COMMUNITY MOBILIZATION

\begin{tabular}{|c|c|c|c|c|}
\hline BARANGAY & $\begin{array}{l}\text { COMMUNITY } \\
\text { MOBILIZATION } \\
\text { PARTNERSHIP } \\
\text { WITH NGOS }\end{array}$ & $\begin{array}{l}\text { PARTNERSHIP } \\
\text { WITH } \\
\text { EDUCATIONAL } \\
\text { INSTITUTIONS }\end{array}$ & $\begin{array}{l}\text { COMMUNITY MOBILIZATION. THE } \\
\text { BARANGAYS FARED WELL IN MAKING } \\
\text { PARTNERSHIP WITH PEOPLE'S } \\
\text { ORGANIZATIONS (POS) IN IMPLEMENTING } \\
\text { BARANGAY PROJECTS, PROGRAMS, AND } \\
\text { ACTIVITIES }\end{array}$ & $\begin{array}{l}\text { THE ALTERNATIVE } \\
\text { LEARNING SYSTEM } \\
\text { (ALS), AND OTHER } \\
\text { PROJECTS IN THE } \\
\text { BARANGAYS. }\end{array}$ \\
\hline San Lorenzo & $\begin{array}{l}10 \mathrm{NGOs} \text { accredited in } \\
\text { the barangay }\end{array}$ & $\begin{array}{l}\text { Yes in private } \\
\text { schools in the } \\
\text { area }\end{array}$ & $\begin{array}{l}\text { There are NGO members in all Barangay - } \\
\text { Based Institutions particularly the Barangay } \\
\text { Development Council }\end{array}$ & Yes (Barangay -Based) \\
\hline San Antonio & 12 & Both public and private & $\begin{array}{l}\text { There are NGO members in all Barangay -Based } \\
\text { Institutions particularly the Barangay } \\
\text { Development Council }\end{array}$ & $\begin{array}{l}\text { Yes (Partnership with } \\
\text { Public Schools) }\end{array}$ \\
\hline Poblacion & 15 & Both public and private & $\begin{array}{l}\text { There are NGO members in all Barangay -Based } \\
\text { Institutions particularly the Barangay } \\
\text { Development Council }\end{array}$ & $\begin{array}{l}\text { Yes (Partnership with Public } \\
\text { Schools) }\end{array}$ \\
\hline $\begin{array}{l}\text { Post Proper } \\
\text { Northside }\end{array}$ & 6 & Public schools only & $\begin{array}{l}\text { There are NGO members in all Barangay -Based } \\
\text { Institutions particularly the Barangay } \\
\text { Development Council }\end{array}$ & $\begin{array}{l}\text { Yes (Partnership with Public } \\
\text { Schools) }\end{array}$ \\
\hline Pembo & 13 & Both public and private & $\begin{array}{l}\text { There are NGO members in all Barangay - Based } \\
\text { Institutions particularly the Barangay } \\
\text { Development Council }\end{array}$ & $\begin{array}{l}\text { Yes (Partnership with Public } \\
\text { Schools) }\end{array}$ \\
\hline $\begin{array}{l}\text { Post Proper } \\
\text { Southside }\end{array}$ & & Private schools only & $\begin{array}{l}\text { There are NGO members in all Barangay -Based } \\
\text { Institutions particularly the Barangay } \\
\text { Development Council }\end{array}$ & $\begin{array}{l}\text { Yes (Partnership with Public } \\
\text { Schools) }\end{array}$ \\
\hline
\end{tabular}


TABLE 10.1 DISTRIBUTION OF THE BARANGAYS IN TERMS OF THE DELIVERY OF SOCIAL SERVICES

\begin{tabular}{|c|c|c|}
\hline BARANGAY & $\begin{array}{l}\text { PROVISION OF THE SOCIAL FACILITIES (- } \\
\text { Barangay Office, Barangay Multi-purpose Hall } \\
\text {,Day Care Center ,Reading Center, Computer } \\
\text { Center, Health Center, Senior Citizens' Affairs, } \\
\text { Women's And Children's Desks, Public Parks, } \\
\text { Public Comfort Rooms, Ramp For PWDs, Sports } \\
\text { Facilities }\end{array}$ & $\begin{array}{l}\text { BARANGAY-ASSISTED HEALTH } \\
\text { PROGRAMS ESPECIALLY THE } \\
\text { MANDATED PPAs }\end{array}$ \\
\hline San Lorenzo & $\begin{array}{l}\text { barangay office, barangay multi-purpose hall } \\
\text {,day care center ,reading center, computer } \\
\text { center, senior citizens' affairs, women's and } \\
\text { children's desks, public parks, ramp for PWDs, } \\
\text { sports facilities }\end{array}$ & $\begin{array}{l}\text { Provide their own clinic in the barangay } \\
\text { hiring a licensed nurse, dentist and } \\
\text { physician and implement PPAs in } \\
\text { coordination with Makati Health }\end{array}$ \\
\hline
\end{tabular}

TABLE 10.2 DISTRIBUTION OF THE BARANGAYS IN TERMS OF THE DELIVERY OF SOCIAL SERVICES

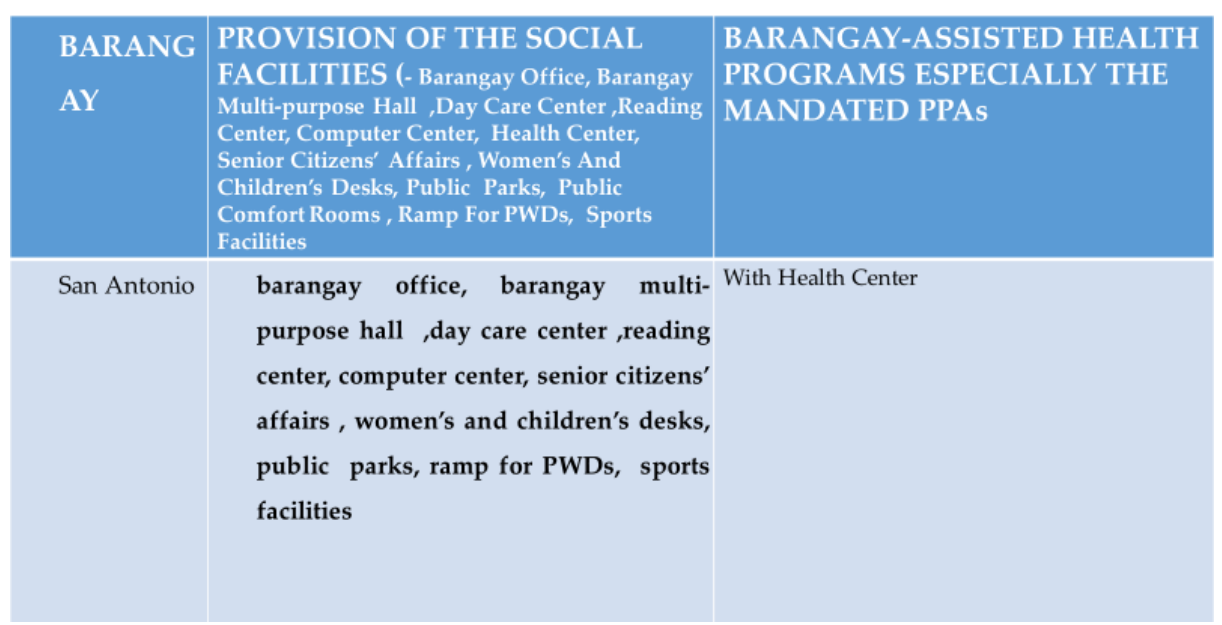

TABLE 10.3 DISTRIBUTION OF THE BARANGAYS IN TERMS OF THE DELIVERY OF SOCIAL SERVICES

\begin{tabular}{|l|l|l|}
\hline BARANGAY & PROVISION OF THE SOCIAL & BARANGAY-ASSISTED \\
FACILITIES (- Barangay Office, & HEALTH PROGRAMS \\
Barangay Multi-purpose Hall, Day Care & ESPECIALLY THE \\
Center, Reading Center, Computer & Center, Health Center, Senior Citizens' \\
Affairs, Women's And Children's Desks, \\
Public Parks, Public Comfort Rooms, \\
Ramp For PWDs, Sports Facilities
\end{tabular}


TABLE 10.4 DISTRIBUTION OF THE BARANGAYS IN TERMS OF THE DELIVERY OF SOCIAL SERVICES

\begin{tabular}{|c|c|c|}
\hline BARANGAY & $\begin{array}{l}\text { PROVISION OF THE } \\
\text { SOCIAL FACILITIES (- } \\
\text { Barangay Office, Barangay Multi- } \\
\text { purpose Hall ,Day Care Center } \\
\text { 'Reading Center, Computer Center, } \\
\text { Health Center, Senior Citizens' } \\
\text { Affairs, Women's And Children's } \\
\text { Desks, Public Parks, Public } \\
\text { Comfort Rooms, Ramp For PWDs, } \\
\text { Sports Facilities }\end{array}$ & $\begin{array}{l}\text { BARANGAY-ASSISTED HEALTH } \\
\text { PROGRAMS ESPECIALLY THE } \\
\text { MANDATED PPAs }\end{array}$ \\
\hline Post Proper Northside & $\begin{array}{l}\text { barangay office, reading } \\
\text { center, computer center } \\
\text { senior citizens' affairs, } \\
\text { women's and children's } \\
\text { desks, public comfort rooms } \\
\text {, ramp for PWDs, sports } \\
\text { facilities }\end{array}$ & $\begin{array}{l}\text { No Health Center but coordinate the Health } \\
\text { Programs, Projects and Activities with Makati } \\
\text { Health Department and West Rembo Health } \\
\text { Center }\end{array}$ \\
\hline
\end{tabular}

TABLE 10.5 DISTRIBUTION OF THE BARANGAYS IN TERMS OF THE DELIVERY OF SOCIAL SERVICES

\begin{tabular}{|c|c|c|}
\hline BARANGAY & $\begin{array}{l}\text { PROVISION OF THE SOCIAL } \\
\text { FACILITIES (- Barangay Office, } \\
\text { Barangay Multi-purpose Hall ,Day Care } \\
\text { Center, Reading Center, Computer Center, } \\
\text { Senior Citizens' Affairs, Women's And } \\
\text { Children's Desks, Public Parks, Public } \\
\text { Comfort Rooms, Ramp For PWDs, Sports } \\
\text { Facilities }\end{array}$ & $\begin{array}{l}\text { BARANGAY-ASSISTED } \\
\text { HEALTH PROGRAMS } \\
\text { ESPECIALLY THE } \\
\text { MANDATED PPAs }\end{array}$ \\
\hline Pembo & $\begin{array}{l}\text { barangay office, barangay multi- } \\
\text { purpose hall ,day care center } \\
\text {,reading center, computer center, } \\
\text { health center, senior citizens' affairs } \\
\text {, women's and children's desks, } \\
\text { public parks, public comfort } \\
\text { rooms, ramp for PWDs, sports } \\
\text { facilities }\end{array}$ & With Health Center \\
\hline
\end{tabular}

TABLE 10.6 DISTRIBUTION OF THE BARANGAYS IN TERMS OF THE DELIVERY OF SOCIAL SERVICES

\begin{tabular}{|c|c|c|}
\hline BARANGAY & $\begin{array}{l}\text { PROVISION OF THE SOCIAL } \\
\text { FACILITIES (- barangay office, } \\
\text { barangay multi-purpose hall ,day care } \\
\text { center, reading center, computer center, } \\
\text { health center, senior citizens' affairs, } \\
\text { women's and children's desks, public } \\
\text { parks, public comfort rooms, ramp for } \\
\text { PWDs, sports facilities }\end{array}$ & $\begin{array}{l}\text { BARANGAY-ASSISTED } \\
\text { HEALTH PROGRAMS } \\
\text { ESPECIALLY THE } \\
\text { MANDATED PPAs }\end{array}$ \\
\hline Post Proper Southside & $\begin{array}{l}\text { barangay office, barangay multi- } \\
\text { purpose hall ,reading center, } \\
\text { computer center, senior citizens' } \\
\text { affairs, women's and children's } \\
\text { desks, ramp for PWDs, sports } \\
\text { facilities }\end{array}$ & $\begin{array}{l}\text { No Health Center but coordinate the } \\
\text { Health Programs, Projects and Activities } \\
\text { with Makati Health Department }\end{array}$ \\
\hline
\end{tabular}


TABLE 11 DISTRIBUTION OF THE BARANGAYS IN TERMS OF THE DELIVERY OF ECONOMIC SERVICES

\begin{tabular}{|c|c|c|c|c|c|}
\hline BARANGAY & $\begin{array}{l}\text { LIVELIHOOD } \\
\text { PROGRAMS }\end{array}$ & $\begin{array}{l}\text { BARANGAY } \\
\text { BUSINESS } \\
\text { ASSOCIATION } \\
\text { ORGANIZATION }\end{array}$ & $\begin{array}{l}\text { JOB } \\
\text { FAIRS }\end{array}$ & $\begin{array}{l}\text { PRESENCE OF } \\
\text { COOPERATIVES }\end{array}$ & $\begin{array}{l}\text { INFRASTRUCTURE } \\
\text { DEVELOPMENT }\end{array}$ \\
\hline San Lorenzo & Yes & Yes & Yes & Yes & Yes \\
\hline San Antonio & Yes & Yes & Yes & No & Yes \\
\hline Poblacion & Yes & Yes & Yes & Yes & Yes \\
\hline $\begin{array}{ll}\text { Post } & \text { Proper } \\
\text { Northside } & \end{array}$ & Yes & Yes & Yes & No & No \\
\hline Pembo & Yes & Yes & Yes & No & Yes \\
\hline $\begin{array}{ll}\text { Post } & \text { Proper } \\
\text { Southside } & \end{array}$ & Yes & Yes & Yes & Yes & No \\
\hline
\end{tabular}

TABLE 12 DISTRIBUTION OF THE BARANGAYS IN TERMS OF THE DELIVERY OF PROTECTIVE SERVICES

\begin{tabular}{|c|c|c|c|c|c|c|c|}
\hline BARANGAY & & BADAC & BPOC & BDRRM & BARANGAY TANOD & $\begin{array}{l}\text { VOLUNTEER } \\
\text { MARSHALS }\end{array}$ & $\begin{array}{l}\text { PRACTICE OF } \\
\text { HOUSEHOLD } \\
\text { VISITATIONS }\end{array}$ \\
\hline San Lorenzo & & Yes & Yes & Yes & 20 & No & No \\
\hline San Antonio & & Yes & Yes & Yes & 20 & Yes & Yes \\
\hline Poblacion & & Yes & Yes & Yes & 20 & Yes & Yes \\
\hline $\begin{array}{l}\text { Post } \\
\text { Northside }\end{array}$ & Proper & Yes & Yes & Yes & 15 & Yes & Yes \\
\hline Pembo & & Yes & Yes & Yes & 20 & Yes & Yes \\
\hline $\begin{array}{l}\text { Post } \\
\text { Southside }\end{array}$ & Proper & Yes & Yes & Yes & 15 & Yes & Yes \\
\hline
\end{tabular}

TABLE 13 DISTRIBUTION OF THE BARANGAYS IN TERMS OF THE DELIVERY OF ENVIRONMENTAL

\begin{tabular}{|c|c|c|c|c|c|c|c|}
\hline BARANGAY & $\begin{array}{l}\text { PRESENCE OF } \\
\text { BARANGAY } \\
\text { SOLID WASTE } \\
\text { MANAGEMENT } \\
\text { COMMIITEE } \\
\text { (BSWMC }\end{array}$ & $\begin{array}{l}\text { GARBAGE } \\
\text { COLLECTION } \\
\text { AND } \\
\text { DISPOSAL. } \\
\text { SYSTEM }\end{array}$ & $\begin{array}{l}\text { PRESENCE } \\
\text { OF } \\
\text { COMPOST } \\
\text { PIT IN EVERY } \\
\text { HOUSEHOLD }\end{array}$ & $\begin{array}{l}\text { REGULAR } \\
\text { PRACTICE OF } \\
\text { GARBAGE } \\
\text { COLLECTION }\end{array}$ & $\begin{array}{l}\text { PRESENCE OF } \\
\text { GARBAGE } \\
\text { DUMPED } \\
\text { ALONG THE } \\
\text { STREET }\end{array}$ & $\begin{array}{l}\text { PRESENCE OF } \\
\text { FUNCTIONAL } \\
\text { SEWERAGE } \\
\text { SYSTEM } \\
\text { (DRAINAGE } \\
\text { CANAL) }\end{array}$ & $\begin{array}{l}\text { COMPLIANCE } \\
\text { TO MADAMUS } \\
\text { WEEKIY } \\
\text { CLEAN-UP } \\
\text { DRIVE }\end{array}$ \\
\hline San Lorenzo & $\begin{array}{c}\text { Meets } \\
\text { quarterly }\end{array}$ & $\begin{array}{c}\text { Wastes have } \\
\text { been } \\
\text { segregated }\end{array}$ & NONE & $\begin{array}{l}\text { Provided private } \\
\text { contractor }\end{array}$ & NO & Yes & $\begin{array}{l}\text { Every week and } \\
\text { submit weekly } \\
\text { report }\end{array}$ \\
\hline San Antonio & $\begin{array}{l}\text { Meets } \\
\text { monthly }\end{array}$ & $\begin{array}{l}\text { Wastes have been } \\
\text { segregated }\end{array}$ & NONE & $\begin{array}{l}\text { Everyday but no } \\
\text { specific time }\end{array}$ & Yes & Yes & $\begin{array}{l}\text { Every week and } \\
\text { submit weekly } \\
\text { report }\end{array}$ \\
\hline Poblacion & $\begin{array}{c}\text { Meets } \\
\text { quarterly }\end{array}$ & $\begin{array}{l}\text { Wastes have been } \\
\text { segregated }\end{array}$ & NONE & $\begin{array}{l}\text { Everyday but no } \\
\text { specific time }\end{array}$ & Yes & Yes & $\begin{array}{l}\text { Every week and } \\
\text { submit weekly } \\
\text { report }\end{array}$ \\
\hline $\begin{array}{l}\text { Post Proper } \\
\text { Northside }\end{array}$ & $\begin{array}{c}\text { Meets } \\
\text { quarterly }\end{array}$ & $\begin{array}{c}\text { Wastes have been } \\
\text { segregated }\end{array}$ & NONE & $\begin{array}{l}\text { Everyday but no } \\
\text { specific time }\end{array}$ & Yes & Yes & $\begin{array}{l}\text { Every week and } \\
\text { submit weekly } \\
\text { report }\end{array}$ \\
\hline Pembo & $\begin{array}{l}\text { Meets } \\
\text { monthly }\end{array}$ & $\begin{array}{l}\text { Wastes have been } \\
\text { segregated }\end{array}$ & NONE & $\begin{array}{l}\text { Everyday but no } \\
\text { specific time }\end{array}$ & Yes & Yes & $\begin{array}{c}\text { Every week and } \\
\text { submit weekly } \\
\text { report }\end{array}$ \\
\hline Post Proper & Meets & Wastes have been & NONE & Everyday but no & Yes & Yes & Every week and \\
\hline
\end{tabular}




\section{TABLE 14 OUTCOMES: IMPACT OF THE DELIVERY OF BARANGAY SERVICES}

\begin{tabular}{|l|l|l|l|l|l|l|l|}
\hline Barangay & $\begin{array}{l}\text { AVAILABILITY } \\
\text { OF } \\
\text { RESOURCES }\end{array}$ & $\begin{array}{l}\text { DEVELOPMENT } \\
\text { PLANNING AND } \\
\text { FISCAL } \\
\text { ADMINISTRATION }\end{array}$ & $\begin{array}{l}\text { LEGISLATION } \\
\text { AND } \\
\text { COMMUNITY } \\
\text { MOBILIZATION }\end{array}$ & $\begin{array}{l}\text { SOCIAL. } \\
\text { SERVICES }\end{array}$ & $\begin{array}{l}\text { ECONOMIC } \\
\text { SERVICES }\end{array}$ & $\begin{array}{l}\text { PROTECTIVE } \\
\text { SERVICES }\end{array}$ & $\begin{array}{l}\text { ENVIRONMENTAL. } \\
\text { SERVICES }\end{array}$ \\
\hline $\begin{array}{l}\text { San } \\
\text { Lorenzo }\end{array}$ & HIGH & HIGH & HIGH & HIGH & HIGH & HIGH & HIGH \\
\hline $\begin{array}{l}\text { San } \\
\text { Antonio }\end{array}$ & HIGH & HIGH & HIGH & HIGH & MODERATE & HIGH & HIGH \\
\hline $\begin{array}{l}\text { Poblacion } \\
\text { Post }\end{array}$ & HIGH & HIGH & HIGH & HIGH & MODERATE & HIGH & HIGH \\
\hline $\begin{array}{l}\text { Proper } \\
\text { Northside }\end{array}$ & HIGH & HIGH & HIGH & LOW & HIGH & HIGH \\
\hline $\begin{array}{l}\text { Pembo } \\
\text { HembH }\end{array}$ & HIGH & HIGH & HIGH & LOW & HIGH & HIGH \\
\hline $\begin{array}{l}\text { Post } \\
\text { Proper } \\
\text { Southside }\end{array}$ & HIGH & HIGH & HIGH & HIGH & MODERATE & HIGH & HIGH \\
\hline
\end{tabular}

\section{Conclusion}

The six (6) selected barangays in the City of Makati were strong in terms of resource requirements which make possible the production of goods and services in the barangays. In terms of management of resources, the barangays are also strong in development planning. Along fiscal administration, the barangays showed great potential. They had annual budgets and annual revenue plans, as well as revenue codes. They also complied with the budgetary requirements imposed on personal services. However, many barangays lacked a computerbased financial management system. There are computers in the barangays but there is no existing computer-based financial management system. If existing, the barangay treasurers lack the necessary knowledge and skills on how to use the system. In organization and management, the barangays also had moderately high capability. They showed strength in the submission of accomplishment reports and conducting trainings for the barangay council. They had adequate serviceable equipment, and maintain a one-day processing time for issuing barangay related certificates. However, the barangays lacked a manual of operations and they lacked serviceable vehicles. Barangay officers are not equipped with the necessary knowledge and skills in preparing manual of operation. The inadequacy of service vehicle could be due to lack of budget. The barangays were also strong in the area of barangay legislation. All the barangays under study complied with the required number of barangay council sessions of at least twice a month and they also complied with the conduct of general assembly twice a year. The barangays were also strong in community mobilization as they 
had strong linkages with Pos, NGOs, and educational institutions. In their delivery of social services, the barangays favored the maintenance of day care centers, barangay office, public comfort rooms, parks, health station/center and barangay office; they also adhered to the establishment of a barangay justice system. The barangays, however, seem to be weak in the delivery of economic services. Agricultural support was not given much attention at the barangay level because there is much of this support received from the city government. In addition, putting up of economic enterprise in the barangay is not feasible because these barangays are near the city proper. Road maintenance and provision of skills training were the main focus of the barangays in the provision of these services. In the barangays, the provision of agricultural support services and the operation of barangay economic enterprises were carried out the least. For the protective services, the barangays fared well in establishing Barangay Disaster Coordinating Council, Barangay Tanod, and Anti-Drug Abuse Council; but the practice of regular household visitation was not widespread in all the barangays. For environmental services, the barangays performed garbage collection and disposal; however, there are still garbage found in the streets of some barangays. Garbage receptacles are distributed in strategic places in the barangay especially in the streets, however, the residents lack the concern and necessary cooperation. Likewise, functional sewerage system was not found in most World Academy of Science, Engineering and Technology International Journal of Economics and Management Engineering Vol:2, No:10, 2008 International Scholarly and Scientific Research \& Innovation 2(10) 20081216 ISNI:0000000091950263 Open Science Index, Economics and Management Engineering Vol:2, No:10, 2008 waset.org/Publication/1707 barangays. Rural barangays are not usually affected by flood because water finds their way to the riceland. The services delivered by the barangays had effected an improved status among the barangays. There is an increased literacy rate in the barangays, increased barangay total income, increased crime solution efficiency, decreased infant mortality rate, decreased unemployment rate, increased crime solution efficiency. There was also a good barangay police to population ratio; there was no recorded violation of environmental laws; there was an increase in the percentage of households with sanitary toilets; and an increase in access to safe drinking water. However, the barangays are still facing some problems. The mortality rate considerably increased, the barangays' total income still remained to be low, and flood and pollution control programs 
are not properly implemented. Moreover, the barangays still lack the capability in sourcing out funds for their projects and they still depend on the IRA to run the barangay. The barangay officers are afraid to make loans because of the fear on how to manage the amount loan out.

\section{Recommendations}

The barangays should maintain and further improve their existing non-human resources. The development strategies of the barangays should also be reviewed. Moreover, needs assessment should be made prior to the conduct of development plans in the barangays so that the projects, programs, and activities of the barangays will be more relevant and responsive to the needs of the people. Maintenance and further enhancement of participatory governance should be made by conducting a strategic planning and fiscal management training/workshop to further enhance the barangays' capabilities. There is also a need for the barangay officials to be more equipped with the necessary knowledge and skills about barangay governance. Hence, a training/workshop for the barangy officers should be conducted for this purpose. Moreover, the barangays should sustain their strengths and improve their weaknesses. Specifically, the city government should assist the barangays not only in putting up a computer based financial management system but also to train the barangay officers in using the system. The barangay officers should likewise be assisted in the preparation of an operation manual. The barangays should generate more funds. They should harness fully their resource mobilization powers, such as the intensification of assessment and collection of real properties, business, and other local taxes; acceptable and reasonable bases of imposition for various types of fees and charges should be explored; and review of the non-tax revenue options available to them should be done. They should also prioritize the allocation of their limited resources. This will also help the barangays in the acquisition of service vehicles. On economic services, the barangays should sustain the conduct of skills trainings. Trainings should not only focus on the production of materials, entrepreneurial skills training should likewise be conducted. The barangay residents should not only how to produce materials, they should also know how to sell what had been produced. On the problem of residents dumping garbage in the streets, values development seminar should be conducted at the barangay level. On flood and pollution, there should be 
a strict implementation of flood and pollution control programs like the Clean Air Act in the barangays. On sources of funds, the barangays should be trained on fiscal management to develop their confidence in availing of loans and making joint ventures with the business sectors. In addition, the city government can create a livelihood and investment program which could be availed by the barangays. Furthermore, the barangays should implement cost effective methods of data gathering and processing, as well as the building of a Computerized Barangay Data Bank, not just a simple barangay data bank. Series of trainings on Information and Communication Technology (ICT) should therefore be conducted at the city level to be participated by the barangay officers. These trainings will not only equip the barangay officers with the knowledge and skills in ICT but to develop their awareness on the importance of ICT in barangay governance. Monitoring of the skills learned by the barangay officers and evaluation of the effects of these trainings should be made. Finally, there should be a continuous monitoring of the performance of the barangays.

\section{Acknowledgment}

The researcher is very grateful to the College of Continuing and Advance Professional Studies (CCAPS) of the University of Makati (UMAK) especially to Dean Ederson Tapia and to our class Adviser, Dr Alex Brillantes. Gratitude is aslo extended to the 6 Punong Barangays and Barangay Secretaries of the City of Makati. 